\title{
Applying Missouri Mathematics Project Model in Enhancing Math Learning Outcomes
}

\author{
Nur Widyawati \\ Sekolah Tinggi Ilmu Administrasi \& Manajemen Kepelabuhanan \\ Barunawati Surabaya, Indonesia
}

\begin{abstract}
The objective of this study was to determine the effect of the application of Missouri Mathematics Project (MMP) learning models on improving student learning outcomes. The problems discussed in this study was to describe the activities of teachers and students, results and completeness of student learning as well as students' responses using Missouri Mathematics Project (MMP). Missouri Mathematics Project (MMP) is a structured learning models packaged in several steps: review, development, controlled exercise, seat work and assignments. Samples were 26 students of Islamic school Husain Ibn Surabaya, Indonesia. The research instrument is the students, daily test. This research was conducted in two cycles. The results using the learning model of Missouri Mathematics Project (MMP) in the learning process showed that: (1) there is an increased activity of the teacher; (2) there is an increased activity of students; (3) there is an increase in student learning outcomes; (4) there is an increasing mastery of student learning outcomes; and (5) student response was very good.
\end{abstract}

Keywords: Missouri Mathematics Project (MMP), learning outcomes, students, teachers

\section{INTRODUCTION}

Mathematics is a means to inculcate the habit of using the reasoning in the mindset of someone (Jannah et al., 2013). For most students, math is a subject that is considered difficult, most boring and most frightening and even it is considered as the most significant contributor of students, failure in national final examination.

Madrasa Ibn Husain is one of the Islamic secondary school in Surabaya. The school is more emphasis on soft skills of students morals than hard skill so that most students do not have the motivation to improve ability in regular school subjects, including mathematics. In addition the average score of a math lesson in the school falls below the average. This because teachers are still applying the conventional study in presenting the material resulting in students are less interested in math. Understanding and student learning outcomes also decrease.

According to Jannah et al., (2013), the term model can be understood as a conceptual framework that is used as a guideline for conducting an activity. The learning model is a conceptual framework that describes the procedure for systematically organizing learning experiences to achieve a particular purpose and serves as a guide to plan and carry out a study.

Missouri Mathematics Project (MMP) is a model of structured learning. Step-by-step learning model MMP is a review, development, cooperative work, self-employment and assignment (Jannah et al., 2013). The five steps are expected to obtain increasing students' mathematics learning outcomes better than ever. According to Mustafa (2013), MMP learning model provides the opportunity for students and teachers to be proactive in the learning process. In applying the MMP learning, teacher serves as a facilitator. In addition, the learning model of MMP also coaches cooperation among students in the worksheets of students so that students help each other solving their difficulties and share their thoughts.

Based on the above, the researchers will conduct studies in $9^{\text {th }}$ grade of Madrasa Husain Ibn Surabaya applying Missouri Mathematics Project (MMP) learning model.

\section{LiTERATURE REVIEW}

MMP learning model is a structured learning model as well as the structure of the learning of Mathematics packaged in a few, namely: 
a. Review: 1. Review the material and, 2. Discussing Homework

b. Development:

1. Presentation of a new idea or expansion of math concepts earlier.

2. Explanation, discussion and demonstration with real example.

c. Controlled exercise: 1 . Students respond to questions

a.2. teachers observe

a.3. cooperative learning

d. Seat work: students work on exercises individually

e. Assignment / homework (Nugroho et al., 2012)

MMP learning model, has several advantages, including:

- Many materials can be conveyed to the students because it is not too time consuming. That is, the use of time can be set relatively tight.

- Many practice so that the student is trained with various problems.

In addition to the advantages, MMP learning model also has deficiencies, including: less placing students in an active position and students may get bored because they have to do more listening.

The learning result is a change in behavior as a whole and not just one aspect of human potential only. That is, the learning outcomes categorized by education experts as mentioned above is not seen as fragmentary or separated, but comprehensive (Nugroho et al., 2012). Factors that influence learning outcomes can be divided into three categories, namely: internal factors, external factors and learning approach factors (Arifin, 2010).

\section{Data Collection}

Data analysis techniques used in this research is descriptive statistical analysis. Data analyzed using descriptive statistical analyses are teacher and student activity, completeness of student learning outcomes and students' responses to learning.

Data activity / teacher's ability to manage learning were analyzed by calculating the average of every aspect of the numbers of meetings carried out.

Table4.1. Activities Criteria / Teachers' Capability

\begin{tabular}{|l|l|}
\hline Average Scores $(\mathbf{X})$ & Activities Criteria / Teachers' Capability \\
\hline $4<\mathrm{X} \leq 5$ & Very Good \\
\hline $3<\mathrm{X} \leq 4$ & Good \\
\hline $2<\mathrm{X} \leq 3$ & Average \\
\hline $1<\mathrm{X} \leq 2$ & Poor \\
\hline
\end{tabular}

(Source: Muhlisin, 2010)

Data of student learning activities were analyzed in observation sheet through percentage.

Table4.2. Criteria of Students' Activity

\begin{tabular}{|l|l|}
\hline Percentage (\%) & Criteria of Students' Activity \\
\hline$<25 \%$ & Low \\
\hline $25 \%-50 \%$ & Sufficient \\
\hline $51 \%-75$ & High \\
\hline$>75 \%$ & Very High \\
\hline
\end{tabular}

(Source: Muhlisin, 2010)

Learning outcomes data were analyzed by the summation of all students' test scores obtained and then be divided by the number of students in the class. Students are considered thoroughly have studied if they have reached a score of $\geq 75$ and thoroughly studied classically if reached $\geq 85 \%$ of the number of students (Arifin, 2010). Response data of student learning were analyzed by summing all aspects of student responses. Student learning is successful if reach medium or high with the percentage of $50 \%$ achievement. 


\section{RESULT AND DISCUSSION}

The results of the study for the first cycle and the second cycle are presented in the table below

Table5.1. Result of Research Cycle I and Cycle II

\begin{tabular}{|l|l|l|}
\hline Observation & Cycle I & Cycle II \\
\hline Teachers' activities & $3.92($ Good ) & 3.96 ( Good ) \\
\hline Students' activities & $71.2 \%$ ( High ) & $73.9 \%$ ( High ) \\
\hline Learning Outcomes & 79.1 & 84.8 \\
\hline Learning Completeness & $73 \%$ & $88 \%$ \\
\hline
\end{tabular}

Broadly speaking, the implementation of the first cycle lasted quite well, but there are still some aspects that need improvement, one of which is a classical students, learning completeness that still have not been reached. While on the second cycle there is an increase in the learning process where students' learning completeness has been achieved.

In the first cycle the implementation of learning by teachers already showed good category with a value of 3.92. From observations of researchers, student learning outcomes have been increased, although the completeness of classical study has not yet reached the indicators that have been set. Activities of students in the first cycle showed high class, students listen and pay attention to the explanation of teachers and students also take notes of all the material presented by the teacher. There is an increased student learning outcomes before and after the learning model implemented MMP in the first cycle from 76.7 into 79.1 while the classical learning completeness of students decreased from the pre cycle to cycle I, but the value of pre-cycle students in the majority is more than the number of students from 75 and 76.

In the second cycle the implementation of learning by teachers has been demonstrated in both categories with a value of 3.96. From the observations of researchers learning outcomes of students has increased from the first cycle, both the average value of the class students and students' classical learning completeness. The average value of students increased from 79.1 to 84.8 and completeness of classical study is increased from $73 \%$ to $88 \%$. Activities of students in the second cycle is more active than cycle one where activity of students in the first cycle and the second cycle have something in common that is showing high category, but on the second cycle there is 7 (seven) students who showed an increase from high criteria to very high. There is an increased students, learning outcomes in the second cycle by applying the learning model of MMP. The average value of students is increased from 79.1 to 84.8 . In the second cycle of students' classical learning completeness is increased from $73 \%$ to $88 \%$. This shows that students are interested in MMP learning model thus encouraging students to understand the material.

Student questionnaire results showed that MMP learning model can help address students' mathematics learning difficulties because the application of such models are given a lot of practice questions for students ranging from the provision of sample questions when the teacher explains the material until the daily test is conducted.

According to students, classroom atmosphere is more pleasant by using MMP model because students get a variety of forms to look for a way to resolve problems. Students become more daring to ask and active while learning takes place. Also according to them by using MMP model, it can build cooperation among students in completing the questions given by the teacher on cooperative work steps.

\section{Conclusion}

From the results of research and discussion that has been described, it can be concluded that the application of MMP learning model can improve student learning outcomes in madrasa Ibn Husain Surabaya, Indonesia. The results of this study are:

1. Teacher activity is increased in both categories. It is shown from the observations on the second cycle better than the first one - cycle I: 3.92 and the second cycle: 3.96 with a percentage increase from the first cycle to the second cycle is $1.02 \%$.

2. Activities of students have increased to the high category. The activity of students in the second cycle better than the first one - first cycle: $71.2 \%$ and cycle II: $73.9 \%$ with the percentage increase from the first cycle to the second cycle is $3.9 \%$. 
3. Learning outcomes of students have increased from a pre cycle to cycle I. Average value of precycle: 76.7 and the first cycle: 79.1 with a percentage increase of the pre-cycle to the first cycle is $3.13 \%$. Increased student's learning outcomes of the first cycle to the second cycle is 79.1 to 84.8 with a percentage increase from the first cycle to the second cycle is $7.21 \%$.

4. Classical students' learning is completeness decreased from the pre cycle to cycle I from $96 \%$ to $73 \%$ with the percentage decrease of pre-cycle to the first cycle is $23.96 \%$ and increased from the first cycle to the second cycle is from $73 \%$ to $88 \%$ with the percentage increase from the first cycle to the second cycle is $20.55 \%$.

5. Students' responses from the questionnaire results showed higher category showing that almost all the students enjoy learning model MMP.

\section{REFERENCES}

Arifin, M. Z., 2010, Penerapan Model Pembelajaran Missouri Mathematic Project (MMP) untuk Meningkatkan Hasil Belajar Matematika Materi Pokok Fungsi pada Pederta Didik Kelas VIII MTs. Yasi Kronggen Brati Tahun Pelajaran 2010/2011, Semarang: Fakultas Tarbiyah, Institut Agama Islam Negeri Walisongo. Skripsi tidak untuk dipublikasikan.

Jannah, M., Triyanto dan Ekana, H., 2013, Penerapan Model Missouri Mathematic Project (MMP) untuk Meningkatkan Pemahaman dan Sikap Positif Siswa pada Materi Fungsi, Jurnal Pendidikan Matematika Solusi Vol. 1 No. 1, Maret, 61-66.

Muhlisin, 2010, Peningkatan Hasil Belajar Siswa Melalui Pembelajaran Kooperatif Tipe Think-PairShare dengan Alat Peraga dan Bantuan LKS pada Pokok Bahasan Bangun Ruang Sisi Datar Kelas VI Semester I MI Miftahul Huda Suwawal 01 Pakis Aji Kabupaten Jepara Tahun Pelajaran 2010/2011, Semarang : Fakultas Pendidikan Matematika dan Ilmu Pengetahuan Alam Jurusan Pendidikan Matematika, IKIP PGRI.

Mustofa, N. L., 2013, Meningkatkan Pemahaman Konsep Kesebangunan Matematika Menggunakan Model Pembelajaran MMP (Missouri Mathematic Project), Malang: Pendidikan Matematika, Fakultas Keguruan dan Ilmu Pendidikan, Universitas Muhammadiyah.

Nugroho, P. B., Suparni dan Nu'man, M., 2012, Efektivitas Model Pembelajaran Missouri Mathematic Project (MMP) dengan Metode Talking Stick dan Penemuan Terbimbing Terhadap Hasil Belajar Matematika Siswa, Yogyakarta : Makalah Seminar Nasional Matematika dan Pendidikan Matematika.

Redaksi. 2014. LKS Zamrud SMP Matematika Kelas IX. Surakarta: Putra Nugraha. Halaman 3-19. 